Case Reports

Arch. Esp. Urol. 2009; 62 (3): 236-239

\title{
SEGMENTARY TESTICULAR INFARCTION
}

Jose Maria Sanchez Merino, Jose Carlos Lopez Pacios', Maria del Carmen Piñeiro Fernandez', Sergio Carlos Gomez Cisneros and Jesus Garcia Alonso.

Urology and Emergency Departments'. Hospital del Bierzo. Ponferrada. León. Spain.

Summary.- OBJECTIVE:A new case of segmental testicular infarction is reported.

METHODS: A 52-year-old man presented to the emergency department with severe pain in the left testicle over a few days period. Physical examination revealed a tender induration in the upper pole of the left testicle. $\beta$-human chorionic

José María Sánchez Merino Rua da Zanfona, 3.

Nos (San Pedro)

15176 A Coruña. (España).

sanchezuro@hotmail.com

Accepted for publication: February, $2^{\text {nd }} 2008$. 
gonadotropin and $\alpha$-fetoprotein were normal. Sonography demonstrated a poorly-defined, hypoechoic, $13 \mathrm{~mm}$ lesion. On power Doppler sonography, the hypoechoic area appeared completely avascular in contrast to the rest of the testicle.

RESUITS: Since testicular tumor was the initial diagnosis, the patient underwent a left radical orchiectomy. Pathological study revealed a focal testicular infarction, without signs of malignancy or vasculitis.

CONCLUSIONS: Segmental testicular infarction is usually diagnosed after radical orchiectomy, performed when testicular tumor is suspected.

On certain occasions Doppler ultrasound and magnetic resonance imaging findings suggested a segmental testicular infarction. However, if tumor cannot be entirely excluded, exploratory surgery is necessary.

Keywords: Testis. Segmental infarction. Orchiectomy.

Resumen.- OBJETIVO: Se presenta un nuevo caso de infarto segmentario de testículo.

MÉTODOS: Paciente de 52 años que solicitó valoración por dolor en hemiescroto izquierdo de varios días de evolución. En la exploración física presentaba una induración palpable, dolorosa al tacto, en el polo superior del testículo izquierdo. Los marcadores tumorales (b-hCG y a-fetoproteína) fueron normales. En el estudio ultrasonográfico se apreció una lesión nodular hipoecogénica intratesticular izquierda de $13 \mathrm{~mm}$ de diámetro, de bordes ligeramente irregulares, que no mostraba flujo en el análisis con Doppler color.

RESULTADO: Con el diagnóstico de tumoración testicular izquierda se realizó orquiectomía por vía inguinal. Al corte dicha induración se correspondía con un nódulo bien delimitado. El estudio histopatológico mostró que la lesión correspondía a un infarto testicular segmentario, sin evidencia de malignidad ni signos de vasculitis.

CONCLUSIONES: La forma más habitual de diagnóstico del infarto segmentario de testículo se produce durante el estudio histopatológico de las piezas de orquiectomía radical realizadas por sospecha de tumor.

La ultrasonografía con Doppler y la resonancia magnética nuclear tienen alta fiabilidad diagnóstica, si bien puede resultar difícil descartar categóricamente un fumor de testículo. En estos casos se puede recurrir a la exploración con biopsia que confirme la lesión isquémica no tumoral.

Palabras clave: Testículo. Infarto segmentario. Orquiectomía.

\section{INTRODUCCIÓN}

Segmental testicular infarction is a rare event. Most reported cases have no known aetiology and diagnosis is usually made after radical orchiectomy.

A new case of segmental testicular infarction is reported. Testicular tumor was suspected at first, and then radical orchiectomy was performed.

\section{CASE REPORT}

A 52-year-old-man presented with left testicular pain few days in duration. No other symptoms were presented. Physical examination revealed a tender induration in the upper pole of the left testicle. Tumor markers (b-human chorionic gonadotropin and a-fetoprotein) were normal. Sonography (Figure 1) demonstrated an poorly-defined, hypoechoic, $13.2 \times 12.6 \mathrm{~mm}$, intratesticular lesion. On power Doppler sonography, a hypoechoic area appeared completely avascular in contrast to the remainder of the testis.

Since testicular tumor was the initial diagnosis the patient underwent a left radical orchiectomy.

An abnormal hardening, well-defined, haemorrhagic, $1.7 \mathrm{~cm}$, was palpable in the upper pole. Gross surgical specimen showed an untouched tunica albuginea and well-defined lesion (Figure 2).

Pathological study revealed a focal testicular infarction, without signs of malignancy or vasculitis (Figure 3).

\section{DISCUSSION}

Segmental infarction is uncommon and aetiology is unclear. Most cases are considered idiopathic, although some disorders have been involved as causative factors (sickle cell disease (1), varicocelectomy (2), vasectomy, orchiopexy and epididymitis (3)).

Fernández-Pérez et al. (3) in their series of twelve cases found that median age was 38 years, acute scrotum was the most common presentation $(67 \%)$ and upper or middle part of the testis the most frequent location $(83 \%)$.

Doppler ultrasonography findings may be highly suggestive of segmental testicular infarction, but no conclusive. Segmental testicular infarctions are usually wedge-shaped, avascular lesions, with the vertex at the testicular mediastinum $(3,4)$. However, a round morphology has been also observed (3), the lesion being confused with an intratesticular tumor in theses cases. On the other hand, $86 \%$ of testicular tumors smaller than $1.6 \mathrm{~cm}$ are hypovascular (5). 


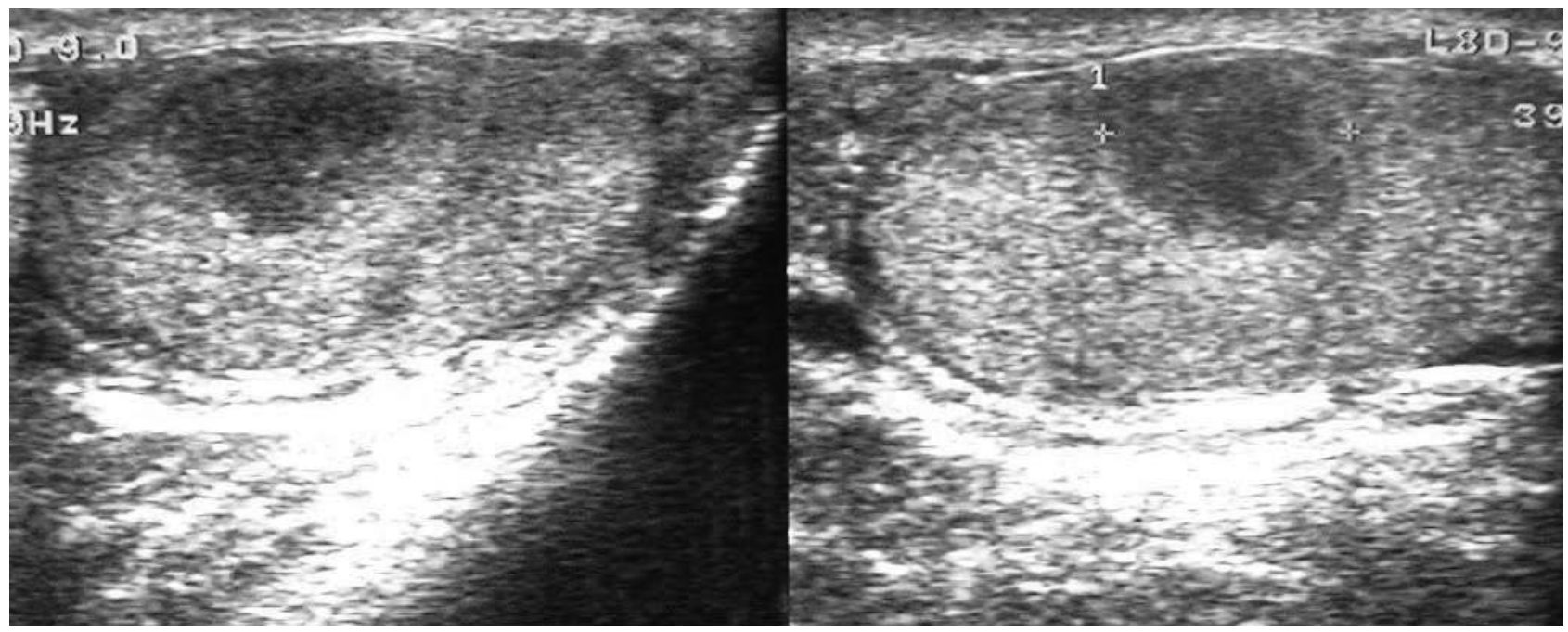

FIGURE 1. Ultrasonography of testicle. A poorly-defined, hypoechoic testicular lesion.

Magnetic resonance imaging (MRI) might be of great value in lesions with a central low intensity area and a peripheral zone with high uptake, strongly suggestive of an ischemic lesion $(3,4)$. But definite exclusion of testicu-

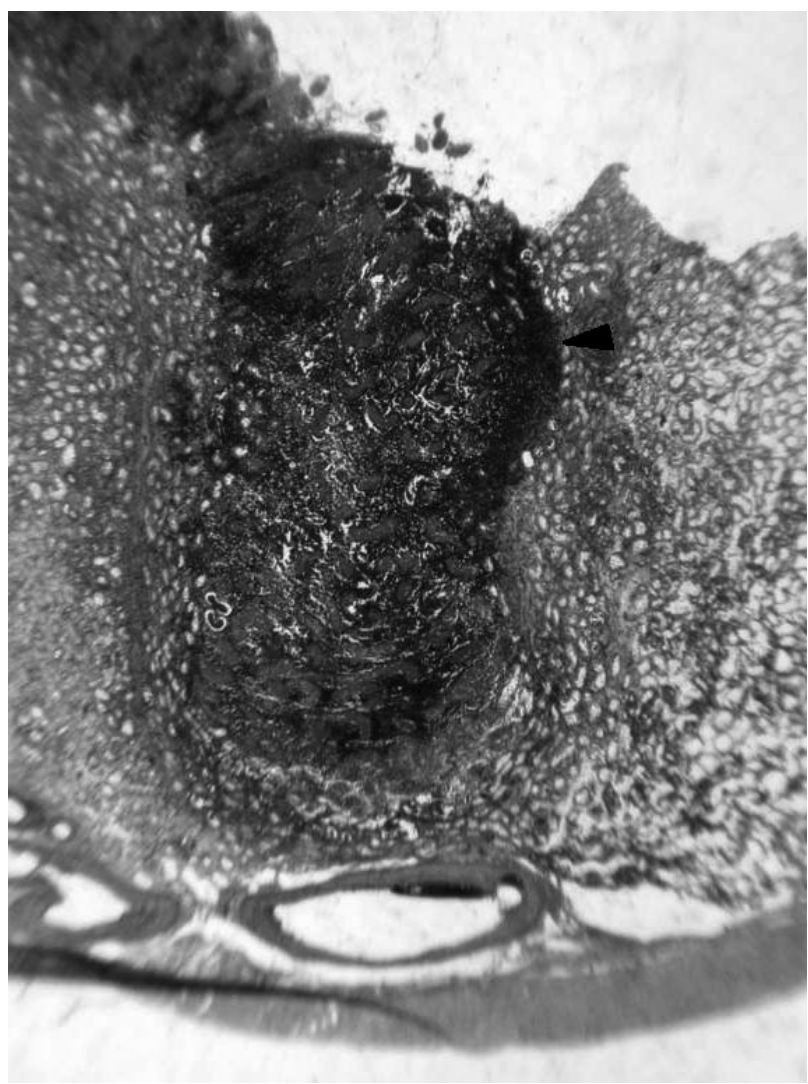

FIGURE 2. Segmental testicular infarction. Photomicrograph shows the segmental infarction, well-defined edge (arrow) and normal testicular parenchyma. lar tumor or abscess is not always possible because MRI may demonstrate different findings for different stages of infarction (6).

Segmental testicular infarction is usually diagnosed after orchiectomy (7). Nevertheless, conservative management (partial orchiectomy) is viable in the presence of a satisfactory history and examination and segmental infarction in excisional frozen biopsy is demonstrated $(4,8)$. With reference to this, Costa et al. (9) suggest open surgery and bivalving the testicle in searching of segmental testicular infarction in those cases with initial diagnosis of testicular torsion, as long as frozen sections for histological confirmation is performed in order to prevent unnecessary orchiectomy.

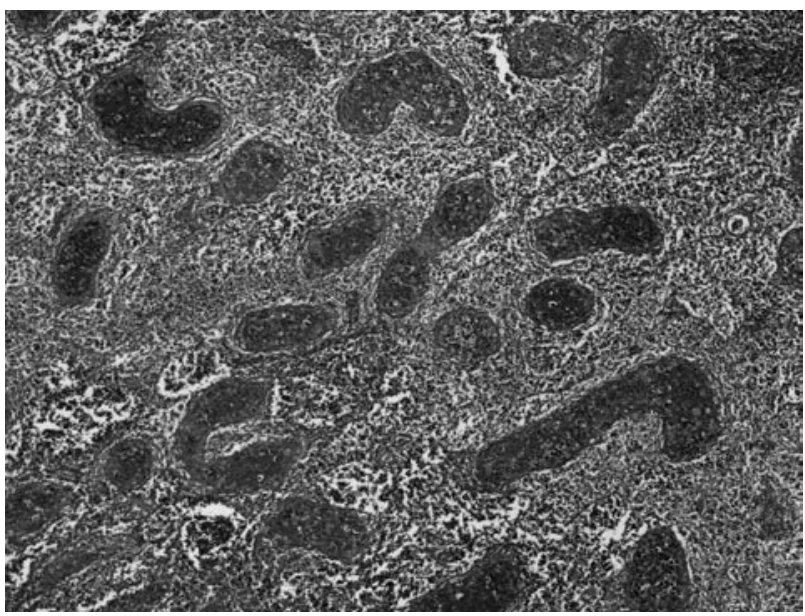

FIGURE 3. Segmental testicular infarction. Shadows of the seminiferous tubules and diffuse segmental interstitial haemorrhage. 
Recently, an increasing number of cases have been treated with partial orchiectomy when segmental testicular infarction is suspected. What is more, expectant management has been communicated if ultrasound and MRI images strongly suggest segmental testicular infarction; in these cases the above-mentioned radiologic techniques would be useful in surveillance (3).

\section{REFERENCES AND RECOMENDED READINGS} ("of special interest, ${ }^{* *}$ of outstanding interest)

1. Gofrit ON, Rund D, Shapiro A, Pappo O, Landau EH, Pode D. Segmental testicular infarction due to sickle cell disease. J Urol. 1998; 160: 835-6.

2. Secil M, Kocyigit A, Aslan G, Kefi A, Ozdemir I, Tuna B, et al. Segmental testicular infarction as a complication of varicocelectomy: sonographic findings. J Clin Ultrasound. 2006; 34: 143-5.

**3. Fernández-Pérez GC, Tardáguila FM, Velasco M, Rivas C, Dos Santos J, Cambronero J, et al. Radiologic findings of segmental testicular infarction. AJR Am J Roentgenol. 2005; 184: 1587-93.

*4. Ruibal M, Quintana JL, Fernández G, Zungri E. Segmental testicular infarction. J Urol. 2003; 170: 187-8.

5. Horstman WG, Melson GL, Middleton WD, Andriole GL. Testicular tumors: findings with color Doppler US. Radiology. 1992; 185: 733-7.

6. Kodama K, Yotsuyanagi S, Fuse H, Hirano S, Kitagawa K, Masuda S. Magnetic resonance imaging to diagnose segmental testicular infarction. J Urol. 2000; 163: 910-1.

7. Ripa Saldías L, Guarch Troyas R, Hualde Alfaro A, de Pablo Cárdenas A, Ruiz Ramo M, Pinós Paul M. Infarto segmentario de testículo. Actas Urol Esp. 2006; 30: 227-30.

8. Hidalgo J, Rodríguez A, Canalias J, Muntané MJ, Huerta MV, Carrasco N, et al. Infarto testicular segmentario vs. tumor testicular: utilidad de la biopsia fría. Arch Esp Urol. 2008; 61: 92-3.

9. Costa M, Calleja R, Ball RY, Burgess N. Segmental testicular infarction. BJU Int. 1999; 83: 525. 